\title{
УДК 641.85
}

\section{СПОСОБ ПОЛУЧЕНИЯ БИОАКТИВИРОВАННЫХ СЕМЯН ОБЛЕПИХИ}

\author{
(C) А.М. Золотарева*, А.В. Щербинина, А.Н. Вторушина
}

\author{
Восточно-Сибирский государственный университет технологий \\ и управления, ул. Ключевская, 40в, Улан-Удэ, 670033 (Россия), \\ e-mail: zolotareva_am@mail.ru
}

Предложен оригинальный способ обработки семян облепихи, позволяющий повысить биологическую ценность исходного сырья. Анализ процесса биоактивации семян облепихи в условиях in vitro позволил выделить общие методологические подходы в регистрации начальных этапов. Как критерий эффективности параметров набухания и темперирования анализировалась способность к биоактивации. Процесс биоактивации семян облепихи исследовали по динамике изменения геометрических параметров семян и определения микроструктуры. Исследование микроструктуры семян имеет большое значение для выявления взаимосвязи между строением и их биологической ценностью. Выявление критических точек дает возможность интегрировать процесс, а учет морфологических особенностей, микроструктуры и химического состава семян - содержание белка, жира, витаминов позволяет ориентироваться в динамике процесса биоактивации. Способ получения биоактивированных семян облепихи предусматривает замачивание семян, обработку ультразвуком, выдержку в течение суток, сушку и измельчение. Под воздействием собственных ферментов морфология и микроструктура анатомических частей семян претерпевает необратимые изменения. Способ биоактивации позволяет улучшить качество семян облепихи за счет повышения их биологической ценности.

Проведена модернизация технологического процесса обработки семян облепихи, позволяющая получить инновационный продукт с сохранением функциональных свойств.

Техническим результатом биоактивации семян облепихи является улучшение качества готового продукта, сокращение длительности процесса, повышение биологической ценности семян, расширение ассортимента пищевых добавок растительного происхождения.

Ключевые слова: технология, биоактивация, семена облепихи, биологически активные вещества.

\section{Введение}

Облепиха - перспективный продукт, как для лекарственного растениеводства, так и для питания в целом. Облепиха является ценным источником ряда важнейших биологически активных соединений. В настоящее время переработка облепихового сырья с использованием традиционных технологий приводит к накоплению большой массы малоиспользуемых отходов. Установлено, что с отходами уходит порядка 2025\% массы исходного сырья. Отходы промышленной переработки облепихи, как правило, не вовлечены в производство из-за высокой ассоциативной связи биологически активных компонентов ягод с компонентами клеточных стенок, несмотря на его ценный химический состав. Изучение специалистами химического состава отходов показывает, что они являются ценным вторичным сырьевым ресурсом [1].

На сегодняшний день ресурсы облепихи направлены в первую очередь на извлечение из нее масла. Побочным продуктом такой переработки являются семена с высоким биохимическим потенциалом, поскольку в них присутствуют не только водо-, но и жирорастворимые биологически активные вещества, не нашедшие на данный момент реального применения [2, 3].

Золотарева Анна Мефодьевна - доктор технических наук, профессор, заведующая кафедрой технологии продуктов из растительного сырья,

e-mail: zolotareva_am@mail.ru

Щербинина Анна Валерьевна - аспирант, e-mail: maxannaval@gmail.com

Вторушина Анастасия Николаевна - аспирант, e-mail: nastya.vtorushina.94@bk.ru
Исходным сырьем для приготовления большого количества разнообразных пищевых продуктов служат семена растений, находящиеся в состоянии покоя. Однако по сравнению с прорастающими семенами в таких «спящих» семенах снижена интенсивность дыхания и обмена веществ,

\footnotetext{
* Автор, с которым следует вести переписку.
} 
сравнительно невелико содержание витаминов и микроэлементов, а запасные вещества находятся в виде сложных молекул белков, жиров и углеводов.

Одним из путей улучшения качества семян различных культур является их проращивание. В результате активации физиологических и биохимических процессов в проращиваемых семенах увеличивается содержание биологически активных веществ.

Доказано, что в процессе проращивания семян происходит повышение пищевой и биологической ценности за счет сбалансированности общего состава аминокислот, в том числе доли незаменимых, а также позволяет уменьшить массовую долю олигосахаридов.

Значительный вклад в изучение аспектов процесса проращивания зерна внесли отечественные исследователи: Е.Д. Казаков, Н.П. Козьмина, О.А. Ильина, Т.Б. Цыганова, В.Д. Малкина, Л.Г. Ипатова, А.А. Кочеткова, А.П. Нечаев и др.

Изменение химического состава зерна при прорастании можно проследить на примере пшеницы (табл. 1).

Процесс проращивания позволяет увеличить количество витаминов и минеральных веществ. Данные витаминного состава пшеничного зерна и пророщенного зерна пшеницы представлены в таблице 2 и показывают, что процесс прорастания пшеницы способствует возрастанию количества витаминов в среднем в $2-$ 4 раза, по сравнению с исходным сухим зерном.

Пророщенные семена облепихи имеют в своем составе чрезвычайно широкий набор полезных веществ, витаминов и микроэлементов и, кроме общего положительного влияния на организм человека, оказывают специфическое оздоравливающее действие, поэтому нашли широкое применение при производстве продуктов питания [4-10].

В настоящее время в литературе приводятся сведения о биоактивации - альтернативном способе повышения биологической ценности семян растений. Биоактивация - это контролируемый процесс, протекающий в присутствии воды, тепла, воздуха и являющийся началом прорастания, в ходе которого происходит трансформация высокомолекулярных веществ в легкодоступные формы. Биоактивация за счет собственных ферментов зерна переводит в легкоусваиваемую форму потенциально питательные вещества [11].

В основе биоактивации корма является ферментативная деструкция высокомолекулярных компонентов и улучшение питательных свойств за счет расщепления белков, углеводов и жиров, а также устранение токсинов и микроорганизмов. Основной показатель биохимических изменений, которые происходят в процессе биоактивации - усиление действия ферментов $[12,13]$. Процесс биоактивации нашел применение для повышения питательной ценности кормов.

Биоактивация осуществляется в промышленных масштабах в ветеринарии при подготовке кормов животным, для повышения их питательной ценности [14-17].

Биоактивация - это экономия энергии корма, направление всей энергии на продуктивное действие (привесы, молоко, репродуктивную способность, здоровье, иммунитет). Биоактивированные семена служат перспективным компонентом в технологиях получения гранулированных комбикормов повышенной пищевой и биологической ценности.

Таблица 1. Изменение химического состава зерна пшеницы при прорастании

\begin{tabular}{c|c|c|c|c|c}
\hline \multirow{2}{*}{ Продукт } & \multicolumn{5}{|c}{ Содержание, г/100 г } \\
\cline { 2 - 6 } & Белки & Углеводы & Сахара & $\begin{array}{c}\text { Липиды (в том числе ненасыщен- } \\
\text { ные жирные кислоты) }\end{array}$ & $\begin{array}{c}\text { Пищевые } \\
\text { волокна }\end{array}$ \\
\hline Зерно мягкой пшеницы & 11.8 & 59.5 & 2.5 & $2.2(1.4)$ & 10.8 \\
Пророщенная пшеница & 7.5 & 41.43 & - & $1.3(0.83)$ & 1.1 \\
\hline
\end{tabular}

Таблица 2. Содержание витаминов в зерне и пророщенном зерне пшеницы (мг на 100 г)

\begin{tabular}{|c|c|c|c|c|c|c|}
\hline \multirow{2}{*}{ Продукт } & \multicolumn{5}{|c|}{ Водорастворимые витамины } & $\begin{array}{c}\text { Жирорастворимые } \\
\text { витамины }\end{array}$ \\
\hline & Тиамин & $\begin{array}{c}\text { Рибофла- } \\
\text { вин }\end{array}$ & $\begin{array}{c}\text { Пантотеновая } \\
\text { кислота }\end{array}$ & $\begin{array}{c}\text { Фолиевая } \\
\text { кислота }\end{array}$ & Ниацин & Токоферол \\
\hline Зерно пшеницы & $0.54-0.11$ & $0.17-0.02$ & $1.12-0.03$ & $0.14-0.005$ & $5.7-1.2$ & 6.1 \\
\hline Пророщенное зерно пшеницы & 0.23 & $0.3-1.45$ & $0.7-3.0$ & $0.3-0.7$ & $3.4-7.5$ & $15-30$ \\
\hline
\end{tabular}


Процесс биоактивации в зависимости от вида семян изучен недостаточно широко, поэтому вопрос изучения биоактивации семян облепихи является актуальным.

Целью работы является разработка способа биоактивирования семян облепихи.

Задачи исследования:

- теоретически обосновать возможность биоактивации семян облепихи;

- разработать способ получения биоактивированных семян облепихи;

- изучить микроструктуру, морфологическую и биохимическую характеристику биоактивированных семян облепихи.

\section{Экспериментальная часть}

Объект исследований. Материалами исследований в эксперименте служили семяна облепихи крушиновидной (Hippophaё rhamnoides L.), собранной с плантаций Республики Бурятия, в период их технической зрелости в 2017-2018 гг., биоактивированные семяна облепихи.

Методы исследования. Экспериментальные исследования проводили на базе лаборатории кафедры «Технология продуктов из растительного сырья» и в Центре коллективного пользования «Прогресс» Восточно-Сибирского государственного университета технологий и управления, лаборатории электронного и рентгеноспектрального микроанализа, отделения молекулярной спектроскопии.

При проведении аналитических исследований использовали современные биохимические, физикохимические методы исследований.

Массовую долю влаги определяли методом высушивания навески до постоянной массы при температуре $100-105^{\circ} \mathrm{C}$ по ГОСТ 13586.5-2015.

Определение общего азота - методом минерализации органических соединений с последующим определением азота по количеству образовавшегося при отгонке аммиака по ГОСТ Р 54390-2011.

Общий сахар и редуцирующие сахара - по ГОСТ 875613-87. Продукты переработки плодов и овощей. Методы определения сахаров.

Массовую долю жира устанавливали методом Сокслета с использованием легколетучих растворителей путем многократной экстракции жира из сухой навески.

Массовую долю «сырой» клетчатки определяли по методу Геннесберга и Штомана. «Сырую» клетчатку получают в результате последовательной обработки навески кислотой и щелочью в условиях, имитирующих действие среды пищеварительного тракта организма, ГОСТ 31675-2012.

Массовую долю пектиновых веществ - весовым кальциево-пектиновым методом.

Массовую долю крахмала определяли объемным методом по Х.Н. Починку.

Содержание токоферола, аскорбиновой кислоты - на анализаторе «Флюорат-02» с приставкой ВЭЖХ. Метод определения заключается в щелочном гидролизе пробы, экстракции гексаном неомыляемой части, в введении экстракта на ВЭЖ-приставку для хроматографического разделения витаминов А и Е и их количественного определения. Метод определения аскорбиновой кислоты основан на извлечении витамина С из пищевого продукта водным раствором уксусной кислоты и фосфорного ангидрида, обработке экстракта активированным углем с целью его очистки и одновременного окисления аскорбиновой кислоты (АК) в дегидроаскорбиновую (ДАК) и последующем проведении реакции с о-фенилендиамином в слабокислой среде с образованием флуоресцирующего соединения и количественного определения суммарного содержания АК и ДАК.

Содержание каротиноидов определяли спектрофотометрическим методом, сущность которого заключается в измерении оптической плотности экстракта пигментов на спектрофотометре при длине волны, соответствующей максимуму поглощения каротиноидов (440.5 нм), с последующим расчетом концентрации пигментов.

Содержание витаминов $\mathrm{B}_{1}, \mathrm{~B}_{2}, \mathrm{~B}_{3}, \mathrm{~B}_{5}, \mathrm{~B}_{6}$ изучали на ИК-Фурье спектрофотометре Nicolet-380.

Сумму флавоноидов - спектрофотометрически в пересчете на рутин.

Аминокислотный состав белков определяли методом системо капиллярного электрофореза Капель-105 М. Содержание жирных кислот - методом ГЖХ. Липиды семян облепихи выделялись смесью хлороформа и метанола в соотношении $2: 1$. Анализ метиловых эфиров жирных кислот (МЭЖК) проводили на газожидкостном хроматографе с пламенно-ионизационным детектором. ГОСТ 30418-96, ГОСТ 316652012, ГОСТ 31663-2012. 
Массовую долю минеральных веществ определяли методом сжигания и последующего озоления навески с дальнейшим прокаливанием минерального остатка в муфельной печи при температуре $500-700{ }^{\circ} \mathrm{C}$ в течение 5-6 ч до постоянной массы.

Определение микроструктуры зерна и муки из семян - на электронном микроскопе JSM-6510LVJEOL с системой микроанализа INCA.

Динамику изменения геометрических параметров семян устанавливали с использованием автоматизированной программы «Zerno».

Математическую обработку результатов проводили с использованием программ Excel, StartPlus.

Повторность опытов физико-химических методов исследования - 3-6 кратная.

\section{Обсуждение результатов}

Нами в эксперименте изучена возможность биоактивации семян облепихи.

Способ получения биоактивированных семян облепихи (БСО) предусматривает следующие этапы:

- замачивание семян;

- обработка ультразвуком в течение 4-6 мин;

- выдерживание в течение 24 ч;

- сушка при температуре $75{ }^{\circ} \mathrm{C}$ до влажности $14 \%$;

- измельчение до размера 100 мкм.

Техническим результатом способа получения биоактивированных семян облепихи является улучшение качества готового продукта, сокращение длительности процесса, повышение биологической ценности семян, расширение ассортимента пищевых добавок растительного происхождения.

Указанный технический результат достигается тем, что в способе получения биоактивированных семян облепихи, предусматривающем замачивание семян и обработку ультразвуком, выдержку во влажном состоянии, сушку до влажности $14 \%$ и измельчение. Согласно изобретению после замачивания семена обрабатывают ультразвуком в течение 3-7 мин, затем выдерживают в течение 24 ч.

В литературе приводятся сведения по ускорению процесса проращивания с использованием активации водных растворов. Вода может быть активирована различными способами, в том числе ультразвуком. Ультразвуковая обработка семян интенсифицирует процесс прорастания, повышает урожайность различных культур в среднем на 20-40\%. При обработке семян ультразвуком в них можно вносить необходимые микроэлементы, уничтожать возбудителей болезней и вредителей, активизировать ферменты [18].

Биоактивацию семян растений осуществляют путем замачивания. Известно, что в первые сутки происходит значительное изменение биополимеров под действием собственных ферментов. Существенными отличительными признаками предлагаемого изобретения являются новые условия обработки семян облепихи, а именно обработка ультразвуком замоченных в воде семян и выдержка их в течение суток.

При этом происходит биоактивация семян - биологический процесс, представляющий собой начальную стадию жизненного цикла растения. Процесс сопровождается активацией ферментных систем. Ферменты зародыша разлагают высокомолекулярные соединения в более простые формы, которые становятся легкоперевариваемыми и усвояемыми в желудочно-кишечном тракте человека.

В ходе исследований по заявляемому способу после замачивания семян водные растворы активировали ультразвуком на аппарате с заданной частотой 25 Гц в течение 3, 4, 5, 6, 7 мин [19]. Процесс биоактивации семян облепихи исследовали по динамике изменения геометрических параметров семян.

Изображение семян получали с помощью сканера. Динамику изменения геометрических параметров семян определяли с использованием автоматизированной программы. Для опытов брали семена в количестве 50 шт., которые помещали на сканирующую поверхность. Динамика изменения геометрических параметров семян облепихи представлена в таблице 3. За контроль взяты семена облепихи без обработки, БСО биоактивированные заявляемым способом семена облепихи.

Из данных таблицы 3 следует, что ультразвуковая обработка способствует увеличению геометрических размеров семян облепихи. Наилучшим показателем является обработка ультразвуком в течение 4-6 мин, при этом геометрические параметры увеличились на $9 \%$ по сравнению с контролем. При обработке ультразвуком в течение 3 мин геометрические параметры семян увеличились на $6 \%$, при 7 мин - на 7\% по сравнению с контролем. 
Таблица 3. Динамика изменения геометрических параметров семян облепихи

\begin{tabular}{|c|c|c|c|c|c|c|c|c|c|c|}
\hline \multirow{3}{*}{ Показатели } & \multicolumn{10}{|c|}{ УЗ обработка, мин } \\
\hline & \multicolumn{2}{|c|}{3} & \multicolumn{2}{|c|}{4} & \multicolumn{2}{|c|}{5} & \multicolumn{2}{|c|}{6} & \multicolumn{2}{|c|}{7} \\
\hline & Контроль & БСО & Контроль & БСО & Контроль & БСО & Контроль & БСО & Контроль & БСО \\
\hline Длина, мм & 4.87 & 5.0 & 4.87 & 5.31 & 4.93 & 5.23 & 4.87 & 5.03 & 4.88 & 4.90 \\
\hline $\mathrm{Max} / \mathrm{min}$ & $6.05 / 3.76$ & $6.09 / 3.79$ & $6.07 / 3.76$ & $6.44 / 4.21$ & $6.66 / 3.67$ & $6.92 / 3.79$ & $5.90 / 3.83$ & $6.13 / 3.43$ & $5.88 / 3.81$ & $5.90 / 3.55$ \\
\hline Ширина, мм & 2.75 & 2.8 & 2.75 & 3.03 & 2.8 & 2.98 & 2.82 & 2.98 & 2.75 & 2.8 \\
\hline $\mathrm{Max} / \mathrm{min}$ & $3.30 / 2.02$ & $3.88 / 2.06$ & $3.31 / 2.08$ & $430 / 2.32$ & $3.40 / 2.09$ & $3.83 / 2.06$ & $3.58 / 2.06$ & $3.84 / 2.07$ & $3.31 / 2.08$ & $3.40 / 2.08$ \\
\hline Дисперсия & 0.50 & 0.60 & 0.50 & 0.69 & 0.57 & 0.59 & 0.51 & 0.57 & 0.50 & 0.54 \\
\hline $\begin{array}{l}\text { Среднеквад- } \\
\text { ратическое } \\
\text { отклонение }\end{array}$ & 0.49 & 0.50 & 0.49 & 0.72 & 0.52 & 0.61 & 0.51 & 0.51 & 0.49 & 0.46 \\
\hline
\end{tabular}

Исследование микроструктуры семян имеет большое значение для выявления взаимосвязи между строением и их биологической ценностью. В клетках растений белки обычно находятся в виде сложных комплексов, почти в каждом комплексе вместе с белками присутствуют углеводы, липиды, нуклеиновые кислоты, минеральные и другие вещества, которые могут быть в свободном состоянии или связаны с белком.

Микроструктуру изучали на поперечных и продольных срезах семян в вакуумной камере электронного сканирующего микроскопа JSM-6510LVJEOL с системой микроанализа INCA* и фотографировали.

Анализ микрофотографий семян облепихи показал, что под воздействием собственных ферментов микроструктура анатомических частей семян претерпевает необратимые изменения. Результаты исследований представлены на рисунках: на рисунке 1 - микрофотографии центральной части эндосперма, поперечный срез при увеличении в 50 раз; на рисунке 2 - микроструктура семян облепихи, поперечный срез при увеличении в 500 раз; на рисунке 3 - микроструктура семян облепихи, продольный срез при увеличении в 500 раз.

При увеличении в 50 раз в поперечном срезе клеточные стенки, мембраны, промежуточный и прикрепленный белок, крупные и мелкие крахмальные гранулы имеют различную скорость набухания и способность удерживать свободную влагу. Эта неравномерность набухания и приводит к возникновению напряжений внутри тканей различных анатомических частей зерна. Внутри клеток эндосперма микротрещины появляются в белковой матрице около крупных зерен крахмала или раскалывают белковую матрицу клетки на крупные куски, что разрыхляет эндосперм (рис. 1).

При поперечном срезе появляются радиальные микротрещины в клетках эндосперма. Проникновение воды в клетки эндосперма сопровождается появлением микротрещин, механически нарушающих природную структуру зерна, поскольку набухание межклеточных и внутриклеточных веществ, имеющих различную биохимическую природу, свойства и назначение, в начальный период увлажнения происходит неравномерно (рис. 2).

Сравнение результатов исследования образцов семян облепихи показало, что при продольном разрезе контрольный образец характеризуется наличием агрегированных продольных включений в виде упорядоченных гранул и приобретает форму в виде сферических глобул. При биоактивации семян наблюдается изменение белковых матриц в связи с денатурацией белка и тем самым влияет на крахмальные гранулы и на белковые прослойки (рис. 3).

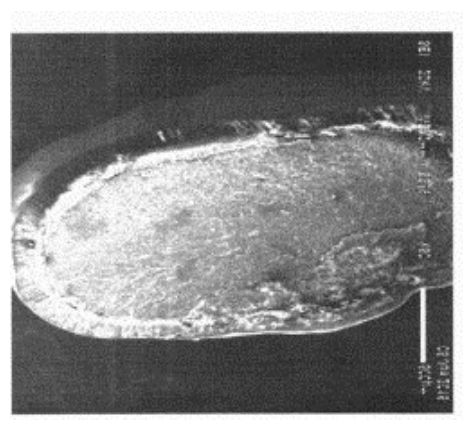

Контроль

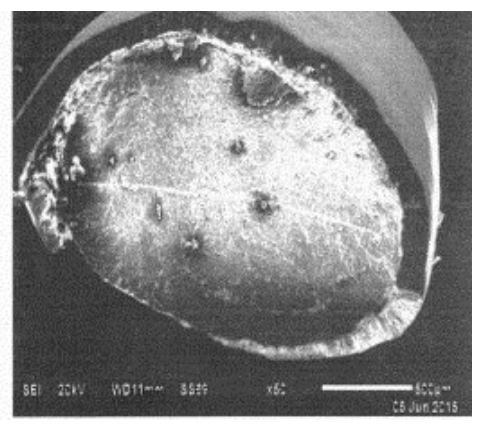

БСO

Рис. 1. Микроструктура семян облепихи ×50 (поперечный срез) 


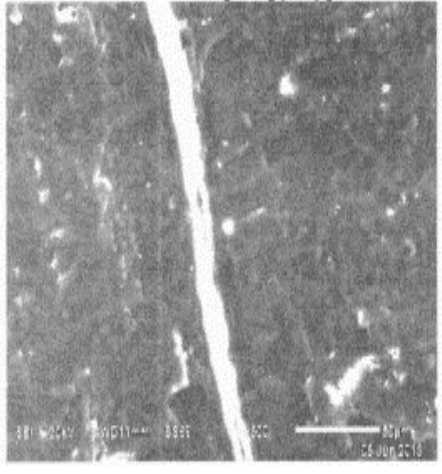

Контроль

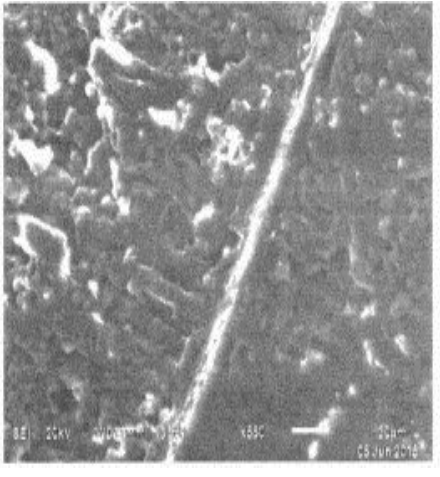

БСО

Рис. 2. Микроструктура семян облепихи ×500 (поперечный срез)

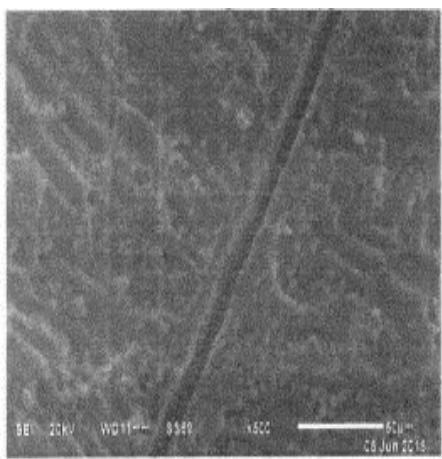

Контроль

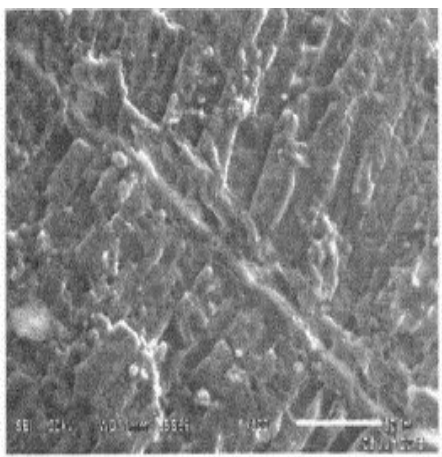

БСО

Рис. 3. Микроструктура семян облепихи ×500 (продольный срез)

Таким образом, ферментативные процессы, протекающие при биоактивации, приводят к цитологическим изменениям, нарушениям клеточной структуры и частичному растворению эндосперма.

В семенах значительное количество ферментов находится в связанном с белками состоянии. Их активация зависит от содержания влаги, которое изменяется при замачивании и проращивании.

Установлено, что при биоативации объем семян увеличивается в среднем на 9\%. Проникающая в семена свободная влага обеспечивает переход в раствор ферментов и питательных веществ и их миграцию к зародышу. Это создает благоприятные условия для проникновения в эндосперм ферментов, которые переводят резервные нерастворимые вещества семян в растворимые и легко усвояемые зародышем. Таким образом, в семенах уменьшается содержание нарастворимых соединений, а растворимых увеличивается. В процессе биоактивации питание зародыша обеспечивается за счет запаса липидов, сахаров, аминокислот и минериальных веществ, которые растворяются в воде.

Изучен химический состав биоактивированных семян облепихи, который приведен в таблице 4.

В результате повышения активности ферментов начинается расщепление высокомолекулярных соединений семян с образованием простых низкомолекулярных соединений, которые расходуются на рост зародыша, что способствует накоплению витаминов и приводит к повышению биологической ценности продукта.

В семенах облепихи присутствует значительное количество белковых веществ $-17 \%$, биологическая ценность которых определяется аминокислотным составом. Аминокислотный состав семян облепихи и БСО представлен в таблице 5 .

Из данных таблицы 3 следует, что суммарное количество аминокислот в БСО составляет в среднем 55.8 мг/л, что на порядок выше, чем в нативных семенах. Причем особенно следует отметить, что в 3 раза увеличилось количество незаменимых аминокислот, таких как фенилаланин, лейцин, изолейцин, что повышает биологическую ценность семян.

Анализ химического состава показывает, что в биоактивированных семенах облепихи увеличивается содержание белков и липидов в среднем более 16 и $10 \%$ соответственно. 
Таблица 4. Химический состав семян облепихи

\begin{tabular}{l|c|c}
\hline \multirow{2}{*}{ Показатели } & \multicolumn{2}{|c}{ Содержание } \\
\cline { 2 - 3 } & Семена облепихи & БСО \\
\hline Белки, \% & $25.06 \pm 0.15$ & $29.62 \pm 0.21$ \\
Липиды, \% & $15.45 \pm 0.11$ & $17.15 \pm 0.75$ \\
Углеводы, \% & $26.67 \pm 0.91$ & $24.67 \pm 0.15$ \\
Клетчатка, \% & $18.21 \pm 0.73$ & $14.18 \pm 0.15$ \\
Пектин, \% & $3.46 \pm 0.02$ & $3.52 \pm 0.02$ \\
Крахмал, \% & $2.71 \pm 0.012$ & $1.66 \pm 0.01$ \\
Моно- и дисахара, в т.ч. редуцирующие, \% & $2.29 \pm 0.11$ & $5.31 \pm 0.02$ \\
Флавоноиды, \% & $1.54 \pm 0.08$ & $2.14 \pm 0.02$ \\
Токоферолы, мг/100 г & $84.01 \pm 2.32$ & $88.52 \pm 0.45$ \\
Каротин, мг/100 г & $4.25 \pm 0.31$ & $4.77 \pm 0.22$ \\
Аскорбиновая кислота, мг/100 г & $6.51 \pm 0.43$ & $8.14 \pm 0.16$ \\
Тиамин, мг/100 г & $1.02 \pm 0.01$ & $1.67 \pm 0.01$ \\
Рибофлавин, мг/100 г & $0.25 \pm 0.01$ & $0.45 \pm 0.01$ \\
\hline
\end{tabular}

Таблица 5. Аминокислотный состав семян облепихи

\begin{tabular}{l|c|c}
\hline \multicolumn{1}{c|}{ Аминокислоты } & Семена облепихи, мг/л & БСО, мг/л \\
\hline Фенилаланин & 0.918 & 2.18 \\
Лейцин+Изолейцин & 1.76 & 7.10 \\
Валин & 1.39 & 2.52 \\
Пролин & 0.565 & 0.847 \\
Серин & 3.21 & 1.91 \\
Глицин & 1.70 & 2.35 \\
\hline
\end{tabular}

Установлено, что суммарное содержание углеводов уменьшилось за счет деструкции высокомолекулярных полисахаридов на 40\%, крахмала - на 22\%, при этом значительно накапливаются моно- и дисахара.

Процесс биоактивации приводит к синтезу флавоноидов и витаминов - таких как аскорбиновая кислота и токоферолы, содержание которых увеличилось на 38,25 и 5\% соответственно.

Биоактивацию семян облепихи характеризует его общая биохимическая направленность путем распада в эндосперме и семядолях высокомолекулярных веществ до низкомолекулярных растворимых веществ при участии влаги и под действием ферментов. Особенность биоактивации заключается в том, что если в эндосперме происходят в основном гидролитические процессы, приводящие к деструкции полисахаридов, то в зародыше преобладают процессы синтеза белков, липидов и витаминов.

Основной показатель глубоких биохимических изменений, происходящих в биоактивированном зерне, - усиление действия ферментов.

При биоактивации в семенах начинается ферментативный гидролиз высокомолекулярных веществ, входящих в состав стенок клеток и запасных веществ эндосперма (целлюлозы, гемицеллюлозы, крахмала), которые, превращаясь в простейшие и растворимые соединения, приобретают способность к диффузии, что позволяет им в дальнейшем использоваться для питания зародыша.

На биосинтез ферментов и образование новых тканей в процессе биоактивации расходуется энергия, которая высвобождается в процессе дыхания зерна, в ходе которого происходит окисление части углеводов. В цитоплазме химическая энергия окисления трансформируется в другие формы и частично расходуется на обмен веществ, а остаток ее выделяется в виде теплоты в окружающую среду.

При биоактивации в семенах осуществляется комплекс взаимосвязанных внешних и внутренних процессов, среди которых можно выделить:

- активацию и биосинтез ферментов в семенах;

- биотрансформацию веществ в семенах в результате каталитического действия ферментов.

Следует особо отметить, биоактивированные семена - это натуральный, природный продукт. Все полезные вещества находятся в них в естественных, сбалансированных количествах и сочетаниях, эти вещества встроены в органическую систему живой ткани. Кроме того, ферменты, образующиеся в прорастающих семенах, расщепляют сложные запасные вещества - углеводы на более простые сахара, которые необходимы для роста будущего растения, поэтому при использовании биоактивированных семян в пищу организм человека тратит гораздо меньше сил на их переваривание и усвоение по сравнению с любыми продуктами, полученными из сухого зерна. 
Прорастающие семена обладают огромным энергетическим потенциалом, содержат все необходимые жизненные компоненты и снабжены системой, которая способствует их усвоению.

\section{Выводы}

Предложен оригинальный способ обработки семян облепихи, позволяющий повысить биологическую ценность исходного сырья. Отличительными признаками заявляемого способа в совокупности с известным обеспечивают улучшение качества готового продукта, сокращение длительности процесса, повышение биологической ценности семян облепихи.

Полученные заявляемым способом биоактивированные семена облепихи содержат комплекс липидов, токоферолов, биофлавоноидов и аскорбиновой кислоты, что позволяет использовать их в качестве перспективного источника при производстве лечебно-профилактических, парфюмерно-косметических продуктов, а также для приготовления корма для животных и птицы.

\section{Список литературь}

1. Золотарева A.M. Основы ресурсосберегающей технологии переработки биомассы Hippophae rhamnoides L.: aвтореф. дис. ... докт. техн. наук. Красноярск, 2004. 46 с.

2. Нямдорж Болорцэцэг. Разработка технологии вареной колбасы с использованием муки из пророщенных семян облепихи: автореф. дис. ... канд. техн. наук. Улан-Удэ, 2018. 19 с.

3. Золотарева А.М. Перспективы совершенствования производства продуктов питания на основе биологически активных веществ облепихи // Известия вузов. Пищевая технология. 2003. №4. С. 55-57.

4. Бережная О.В. Разработка технологии получения проростков зерна пшеницы при производстве хлебопекарной и кулинарной продукции: дис. ... канд. техн. наук. М., 2015. 207 с.

5. Верхотуров В.В., Топорищева В.К. Состояние антиоксидантной системы ячменя при замачивании и солодоращении // Хранение и переработка сельхозсырья. 2003. №9. С. 26-29.

6. Николаенко О.Ю., Корчагин В.П. Соевые проростки и их использование // Пищевая промышленность. 2007. №5. С. 36-37.

7. Петибская В.С., Ефремова Е.Г. Питательная среды соевых проростков // Известия вузов пищевая технология. 2005. №1. С. 36-39.

8. Поландова Р.Д., Котельников Н.Н., Стребыкина А.И. Биоконверсия сои при проращивании и технологии хлебобулочных изделий с ее использованием // Хранение и переработка сельхозсырья. 2005. №7. С. $43-44$.

9. Рахматуллина Ю.Р., Андреева А.А., Кирдяшкин В.В. Термоактивация злаковых культур при производстве продуктов валеологического питания из пророщенных зерен // Хлебопродукты. 2012. №3. С. 50-51.

10. Троценко А.С., Танашкина Т.В. Особенности технологии свежепроросшего гречишного солода // Хранение и переработка сельхозсырья. 2012. №4. С. 10-13.

11. Бабкина И.А. Влияние скармливания проращенного зерна ячменя на рост, сохранность и воспроизводительные функции свиней: автореф. дис. ... канд. с.-х. наук. Майский, 2005. 124 с.

12. Серба Е.М., Оверченко М.Б. Активация ферментов солода и прорастания семян под действием биологически активных веществ гриба Aspergillus oryzae // Хранение и переработка сельхозсырья. 2013. №8. С. 35-38.

13. Пономарева Е.И., Алехина Н.Н. Влияние ферментного препарата целлюлолитического действия на свойства зерна при набухании // Хранение и переработка сельхозсырья. 2012. №10. С. 41-43.

14. Аслалиев А.Д. Исследование и разработка биотехнологического способа обогащения пшеницы селеном для создания БАД: автореф. дис. ... канд. биол. наук. Улан-Удэ, 2011.23 с.

15. Расторгуев В.С. Разработка и эффективность использования новых ЗЦМ и эффективность использования комбикормов-стартеров для телят с включением нетрадиционных компонентов: автореф. дис. ... докт. с.-х. наук. Белгород, 2012. $45 \mathrm{c}$.

16. Хузин Ф.К., Канарская З.А., Ивлева А.Р., Гаматдинова В.М. Совершенствование технологии производства хлебобулочного изделия на основе измельченного проросшего зерна пшеницы // Вестник ВГУИТ. 2017. №1. С. 178-187.

17. Mujoriya R. A study on wheat grass and its nutritional value // Food science and Quality Management. 2011. N2. Pp. 1-8.

18. Соболева О.М. и др. Изменение биометрических показателей проростков пшеницы под влиянием электромагнитного поля // Вестник Алтайского государственного аграрного университета. 2014. №9 (119). С. 45-50.

19. Патент № 2620006 (РФ). Способ получения биологически активной добавки на основе семян облепихи / А.М. Золотарева, С.Б. Ринчинова, А.А. Найданова. - 2017.

Поступила в редакиию 20 января 2020 г.

После переработки 28 сентября 2020 г.

Принята к публикации 28 сентября 2020 г.

Для цитирования: Золотарева А.М., Щербинина А.В., Вторушина А.Н. Способ получения биоактивированных семян облепихи // Химия растительного сырья. 2021. №1. С. 267-275. DOI: 10.14258/jcprm. 2021017314. 
Zolotareva A.M. ${ }^{*}$, Shcherbinina A.V., Vtorushina A.N. METHOD OF OBTAINING BIOACTIVATED SUPPLEMENTS FOR FOOD ON THE BASIS OF SEEDS SEAFLOWS

East Siberian State University of Technology and Management, ul. Klyuchevskaya, 40v, Ulan-Ude, 670033 (Russia), e-mail:zolotareva_am@mail.ru

An original method of treating sea buckthorn seeds has been proposed, which allows to increase the biological value of the feedstock. The analysis of the bioactivation of sea buckthorn seeds in vitro allowed us to identify common methodological approaches in the registration of the initial stages. As a criterion for the effectiveness of swelling and tempering parameters, the bioactivation ability was analyzed. The process of bioactivation of sea buckthorn seeds was investigated by the dynamics of changes in the geometric parameters of seeds, using the automated Zerno program and determining the microstructure. The study of the microstructure of seeds is of great importance to identify the relationship between the structure and their biological value. Identification of critical points makes it possible to integrate the process, and taking into account the morphological features, microstructure and chemical composition of seeds - the content of protein, fat, vitamins allows you to navigate the dynamics of the bioactivation process. A method for producing bioactivated sea buckthorn seeds involves soaking the seeds, sonication, aging for 24 hours, drying and grinding. Under the influence of its own enzymes, the morphology and microstructure of the anatomical parts of the seeds undergoes irreversible changes. The bioactivation method improves the quality of sea buckthorn seeds by increasing their biological value.

The modernization of the technological process for the treatment of sea buckthorn seeds, which allows to obtain an innovative product while maintaining functional properties.

The technical result of bioactivation of sea buckthorn seeds is to improve the quality of the finished product, reducing the duration of the process, increasing the biological value of seeds, expanding the range of food additives of plant origin.

Keywords: technology, bioactivation, sea buckthorn seeds, biologically active substances.

\section{References}

1. Zolotareva A.M. Osnovy resursosberegayushchey tekhnologii pererabotki biomassy Hippophae rhamnoides L.: avtoref. dis. ... dokt. tekhn. nauk. [Fundamentals of resource-saving biomass processing technology Hippophae rhamnoides L.: author. dis. ... doct. tech. sciences]. Krasnoyarsk, 2004, 46 p. (in Russ.).

2. Nyamdorzh Bolortsetseg. Razrabotka tekhnologii varenoy kolbasy s ispol'zovaniyem muki iz proroshchennykh se-myan oblepikhi: avtoref. dis. ... kand. tekhn. nauk. [Development of the technology of boiled sausage using flour from sprouted sea buckthorn seeds: author. dis. ... Cand. tech. sciences]. Ulan-Ude, 2018, 19 p. (in Russ.).

3. Zolotareva A.M. Izvestiya vuzov. Pishchevaya tekhnologiya, 2003, no. 4, pp. 55-57. (in Russ.).

4. Berezhnaya O.V. Razrabotka tekhnologii polucheniya prorostkov zerna pshenitsy pri proizvodstve khlebopekarnoy $i$ kulinarnoy produktsii: dis. ... kand. tekhn. nauk. [Development of technology for obtaining wheat seedlings in the production of bakery and culinary products: dis. ... Cand. tech. sciences]. Moscow, 2015, 207 p. (in Russ.).

5. Verkhoturov V.V., Toporishcheva V.K. Khraneniye i pererabotka sel'khozsyr'ya, 2003, no. 9, pp. 26-29. (in Russ.).

6. Nikolayenko O.Yu., Korchagin V.P. Pishchevaya promyshlennost', 2007, no. 5, pp. 36-37. (in Russ.).

7. Petibskaya V.S., Yefremova Ye.G. Izvestiya vuzov pishchevaya tekhnologiya, 2005, no. 1, pp. 36-39. (in Russ.).

8. Polandova R.D., Kotel'nikov N.N., Strebykina A.I. Khraneniye i pererabotka sel'khozsyr'ya, 2005, no. 7, pp. 43-44. (in Russ.).

9. Rakhmatullina Yu.R., Andreyeva A.A., Kirdyashkin V.V. Khleboprodukty, 2012, no. 3, pp. 50-51. (in Russ.).

10. Trotsenko A.S., Tanashkina T.V. Khraneniye i pererabotka sel'khozsyr'ya, 2012, no. 4, pp. 10-13. (in Russ.).

11. Babkina I.A. Vliyaniye skarmlivaniya prorashchennogo zerna yachmenya na rost, sokhrannost' $i$ vosproizvoditel'nyye funktsii sviney: avtoref. dis. ... kand. s.-kh. nauk. [Influence of feeding the germinated grain of barley on the growth, safety and reproductive functions of pigs: author. dis. ... Cand. s.-kh. sciences]. Mayskiy, 2005, 124 p. (in Russ.).

12. Serba Ye.M., Overchenko M.B. Khraneniye i pererabotka sel'khozsyr'ya, 2013, no. 8, pp. 35-38. (in Russ.).

13. Ponomareva Ye.I., Alekhina N.N. Khraneniye i pererabotka sel'khozsyr'ya, 2012, no. 10, pp. 41-43. (in Russ.).

14. Aslaliyev A.D. Issledovaniye i razrabotka biotekhnologicheskogo sposoba obogashcheniya pshenitsy selenom dlya sozdaniya BAD: avtoref. dis. ... kand. biol. nauk. [Research and development of a biotechnological method for enriching wheat with selenium for the creation of dietary supplements: author. dis. ... Cand. biol. sciences]. Ulan-Ude, 2011, 23 p. (in Russ.).

15. Rastorguyev V.S. Razrabotka i effektivnost' ispol'zovaniya novykh ZTSM i effektivnost' ispol'zovaniya kombikormovstarterov dlya telyat s vklyucheniyem netraditsionnykh komponentov: avtoref. dis. ... dokt. s. $-k h$. nauk. [Development and efficiency of using new milk replacer and the efficiency of using starter compound feed for calves with the inclusion of non-traditional components: author. dis. ... doct. s.-kh. sciences]. Belgorod, 2012, 45 p. (in Russ.).

16. Khuzin F.K., Kanarskaya Z.A., Ivleva A.R., Gamatdinova V.M. Vestnik VGUIT, 2017, no. 1, pp. 178-187. (in Russ.).

17. Mujoriya R. Food science and Quality Management, 2011, no. 2, pp. 1-8.

18. Soboleva O.M. i dr. Vestnik Altayskogo gosudarstvennogo agrarnogo universiteta, 2014, no. 9 (119), pp. 45-50. (in Russ.).

19. Patent 2620006 (RU). 2017. (in Russ.).

Received January 20, 2020

Revised September 28, 2020

Accepted September 28, 2020

For citing: Zolotareva A.M., Shcherbinina A.V., Vtorushina A.N. Khimiya Rastitel'nogo Syr'ya, 2021, no. 1, pp. 267275. (in Russ.). DOI: 10.14258/jcprm.2021017314.

\footnotetext{
${ }^{*}$ Corresponding author.
} 
